\title{
Effects and maintenance of a pericentric inversion polymorphism in the grasshopper Aiolopus strepens
}

\author{
E. VISERAS \& J. P. M. CAMACHO \\ Departamento Biologia Animal, Ecologia y Genética, Facultad de Ciencias, Universidad de Granada, 18071 Granada, \\ Spain
}

\begin{abstract}
Seven natural populations of the grasshopper Aiolopus strepens were analysed to investigate the effects of a pericentric inversion in the smallest chromosome $\left(S_{11}\right)$ on chiasma formation and nucleolus organizer regions (NORs) activity. This polymorphism was stable in one population after comparing the frequencies of standard and inverted $\mathrm{S}_{11}$ chromosomes in two samples taken 5 years apart. Furthermore, mean cell chiasma frequency in this population tended to decrease over these 5 years. Males homozygous for the $S_{11}$ inversion showed a higher frequency of inactivity of one of the NORs located on the $\mathrm{L}_{3}$ chromosome than that found in standard homozygous and heterozygous males. The results suggest that this stable polymorphism is maintained by heterosis, and that inversion homozygotes are less fit than standard homozygotes, which explains the low frequency of inverted chromosomes in all populations analysed. However, the possibility of recurrence of the inversion cannot be ruled out.
\end{abstract}

Keywords: Aiolopus strepens, chiasma frequency, NOR activity, pericentric inversion.

\section{Introduction}

Chromosomal inversions in natural populations of grasshoppers seem to show a perfect equilibrium since the frequencies of the different chromosomal types do not change significantly from generation to generation (White, 1958; Lewontin \& White, 1960; White et al., 1963). In Trimerotropis gracilis, the composition of natural populations which were polymorphic for pericentric inversions in chromosomes 5 and 7 did not change between the years 1949 and 1957 (White, 1958). In Keyacris scurra, the frequencies of inversions remain stable for years, although populations only 5 miles apart may differ considerably in cytogenetic composition (Lewontin \& White, 1960).

Inversions in grasshoppers are considered as absolute crossover suppressors since heterozygotes often show asynapsis or straight non-homologous pairing, but not inversion loops, between standard and inverted sequences (White, 1973; Hewitt, 1979). As Hewitt (1979) pointed out, the crossover suppression produced by the inversions, which prevents free recombination of genes within the sequence, is probably a crucial selective attribute, since a new inversion may arise a 'supergene'. This could explain the mainte- nance of stable polymorphisms in perfect equilibrium by heterosis in the above mentioned cases of $T$. gracilis and $K$. scurra, among other species.

We investigated other causes which help to maintain pericentric inversion polymorphism in natural populations of the grasshopper Aiolopus strepens. We analysed the effects of this inversion on chiasma formation and NOR activity in a population, and compared the former character in two samples collected in 1980 and 1985. Furthermore, we analysed six other natural populations to investigate the incidence of polymorphism and to compare chromosomal frequencies in space (between populations) and time (samples from 1980 and 1985 in a specific population).

\section{Materials and methods}

A total of 415 adult males and females of $A$. strepens were caught at seven natural populations in the province of Granada (southeastern Spain, Fig. 1).

The testes were removed from each male through a small cut in the dorsal abdomen, and fixed in $3: 1$ ethanol-acetic acid. The cut was sealed with paraffin and each male was injected with 0.05 per cent colchicine in isotonic insect saline solution. After $6 \mathrm{~h}$, males 


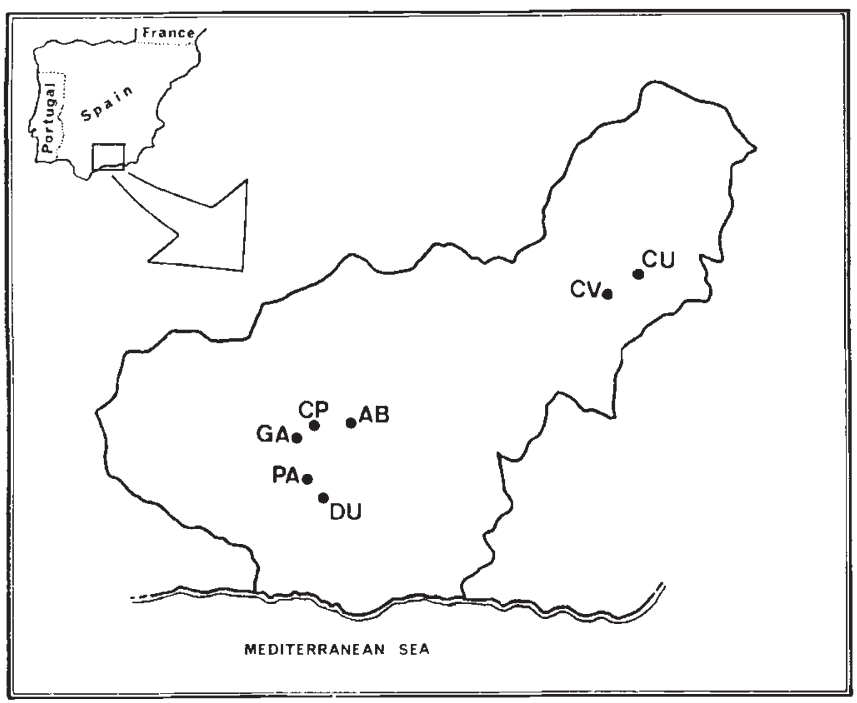

Fig. 1 Map of the Province of Granada showing the location of the seven populations sampled. CU, Cúllar; DU, Dúrcal; GA, Gabias; AB, Río Aguas Blancas; CP, Camino de Purchil; CV, Cañada de las Ventanas; PA, Padul.

were dissected to fix the gastric caeca. Females were injected with 0.05 per cent colchicine $6 \mathrm{~h}$ prior to fixation of the ovarioles and gastric caeca.

A female from population $\mathrm{CP}$ which was gravid when caught was maintained in the laboratory in a culture cage until several egg pods were obtained. The pods were incubated at $27^{\circ} \mathrm{C}$ for 10 days, after which the eggs were dissected and the embryos were immersed in $1 \mathrm{ml} 0.05$ per cent colchicine in isotonic insect saline solution for $1 \mathrm{~h}$. Then $1 \mathrm{ml}$ of distilled water was added for hypotonic shock and the embryos were subsequently fixed in 3:1 ethanol-acetic acid.

The $S_{11}$ chromosomes were characterized in all individuals by studying mitotic chromosomes in the gastric caeca (males and females) and ovarioles (females), by squashing the organ in lacto-propionic orcein. The effects of $S_{11}$ inversion on chiasma frequency and NOR activity were investigated in male meiocytes stained with orcein and silver nitrate. Silver impregnation was done according to the technique described by Rufas et al. (1982).

\section{Results}

The standard individuals of $A$. strepens show a chromosome complement consisting of $2 n=22+\mathrm{XO} /$ $\mathrm{XX}$ subtelocentric chromosomes, with three long $\left(\mathrm{L}_{1}-\mathrm{L}_{3}\right)$, five medium $\left(\mathrm{M}_{4}-\mathrm{M}_{8}\right)$ and three short $\left(\mathrm{S}_{9}-\mathrm{S}_{11}\right)$ autosomal pairs, the $\mathrm{X}$ chromosome being shorter than $\mathrm{L}_{3}$ but longer than $\mathbf{M}_{4}$ (Cabrero \& Camacho, 1982).

All seven natural populations of A. strepens showed variation for the $S_{11}$ chromosome caused by a pericentric inversion which gave rise to a metacentric $S_{11}$ from a standard subtelocentric chromosome (Fig. 2a and $b$ ). We analysed the effects of the inversion in $S_{11}$ on two endophenotypic characters: chiasma frequency and NOR activity in diplotene cells. The number of chiasmata per cell was scored in eight standard homozygous (SS) and eight heterozygotes (SI) males from population $\mathrm{CU}$ (Table 1). Mean chiasma frequency per cell in SI males (17.35) was lower than in SS males (17.88), but the difference was not statistically significant $(t=1.73$, d.f. $=14, P=0.10-0.30)$.

Since $A$. strepens shows only one active NOR located on $\mathrm{L}_{3}$ chromosomes, the only possible way for variation to occur is by the occasional inactivity of the NOR in one of both $\mathrm{L}_{3}$. Our analysis of 20 diplotene cells in each of eight SS males, eight SI males and two II males from population $\mathrm{CU}$ gave the results shown in Table 2. A contingency chi-squared test demonstrated dependence of NOR inactivity on the $S_{11}$ inversion $\left(\chi_{(2)}^{2}=9.27, P=0.001-0.01\right)$. While the frequency of NOR inactivity was similar in SS (14.4 per cent) and SI (17.5 per cent) males, II males showed twice this figure (35 per cent), and this difference was statistically significant, as deduced from a contingency chi-squared

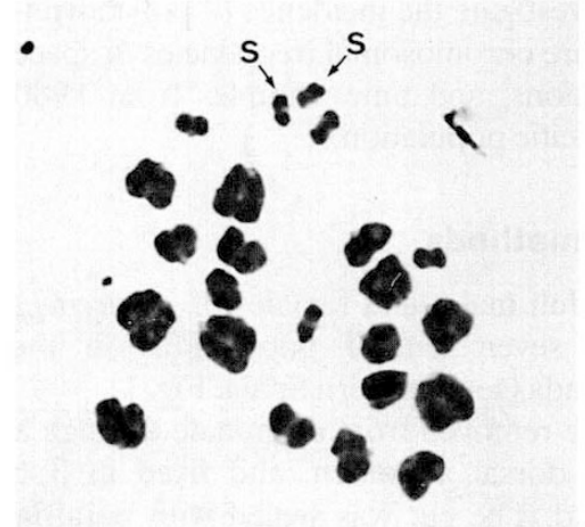

a

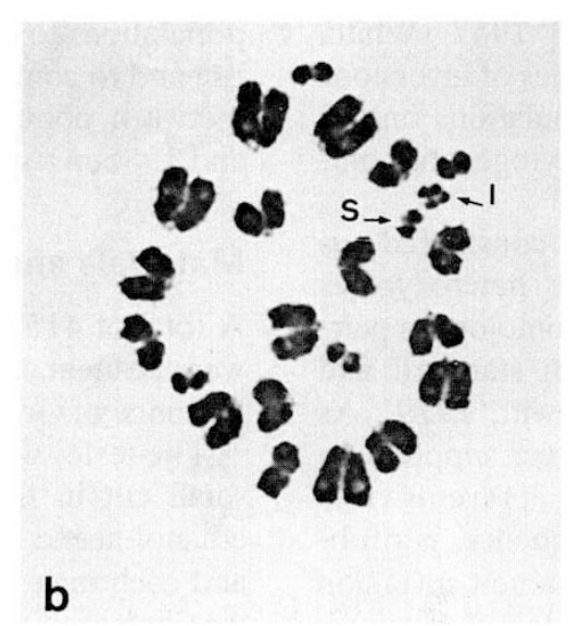

Fig. 2 Gastric caeca mitotic metaphase cells from $(\mathrm{a})$ a standard homozygous individual (SS) (b) an inversion heterozygous individual (SI). Arrows show standard (S) and inverted (I) $\mathrm{S}_{11}$ chromosomes. 
Table 1 Chiasma frequency in eight SS and eight SI males from population CU

\begin{tabular}{|c|c|c|c|c|c|c|c|c|c|c|c|c|c|}
\hline \multirow{2}{*}{$\begin{array}{l}\text { Male } \\
\text { type }\end{array}$} & \multirow{2}{*}{$\begin{array}{l}\text { Male } \\
\text { no. }\end{array}$} & \multicolumn{9}{|c|}{$\begin{array}{l}\text { Number of cells with } 14-22 \text { chiasmata per } \\
\text { cell }\end{array}$} & \multirow{2}{*}{$\begin{array}{l}\text { Total } \\
\text { cells }\end{array}$} & \multirow[b]{2}{*}{$\bar{x}$} & \multirow[b]{2}{*}{$\varepsilon$} \\
\hline & & 14 & 15 & 16 & 17 & 18 & 19 & 20 & 21 & 22 & & & \\
\hline \multirow[t]{8}{*}{ SS } & 6 & - & - & - & 4 & 10 & 5 & - & 1 & - & 20 & 18.20 & \\
\hline & 23 & - & - & 2 & 3 & 14 & 1 & - & - & - & 20 & 17.70 & \\
\hline & 26 & - & 1 & - & 5 & 14 & - & - & - & - & 20 & 17.60 & \\
\hline & 27 & - & - & 3 & 3 & 14 & - & - & - & - & 20 & 17.55 & \\
\hline & 32 & - & - & - & - & 19 & 1 & - & - & - & 20 & 18.05 & \\
\hline & 33 & - & 1 & - & 8 & 6 & 4 & - & 1 & - & 20 & 17.80 & \\
\hline & 42 & - & - & - & 2 & 14 & 4 & - & - & - & 20 & 18.10 & \\
\hline & 78 & - & - & - & 1 & 17 & 2 & - & - & - & 20 & 18.05 & \\
\hline Total & & - & 2 & 5 & 26 & 108 & 17 & - & 2 & - & 160 & 17.88 & 0.088 \\
\hline \multirow[t]{8}{*}{ SI } & 10 & - & - & 2 & 3 & 11 & 2 & 2 & - & - & 20 & 17.95 & \\
\hline & 13 & - & 3 & 3 & 6 & 4 & 4 & - & - & - & 20 & 17.15 & \\
\hline & 18 & - & - & - & 1 & 9 & 5 & 1 & 2 & 2 & 20 & 19.00 & \\
\hline & 35 & - & 1 & - & 4 & 10 & - & - & - & - & 15 & 17.53 & \\
\hline & 39 & - & 2 & 5 & 7 & 5 & 1 & - & - & - & 20 & 16.90 & \\
\hline & 53 & - & 2 & - & 9 & 8 & - & - & - & - & 19 & 17.21 & \\
\hline & 63 & 1 & 5 & 3 & 6 & 4 & - & 1 & - & - & 20 & 16.55 & \\
\hline & 66 & 2 & 3 & 3 & 7 & 4 & 1 & - & - & - & 20 & 16.55 & \\
\hline Total & & 3 & 16 & 16 & 43 & 55 & 13 & 4 & 2 & 2 & 154 & 17.35 & 0.288 \\
\hline
\end{tabular}

$\mathrm{S}=$ Standard $\mathrm{S}_{11} . \mathrm{I}=$ Inverted $\mathrm{S}_{11}$.

Table 2 NOR activity in three types of males according to genotype for the $S_{11}$ inversion

\begin{tabular}{|c|c|c|c|c|}
\hline \multirow[b]{2}{*}{$\begin{array}{l}\text { Male } \\
\text { type }\end{array}$} & \multicolumn{2}{|c|}{ No. of diplotene cells with } & \multirow[b]{2}{*}{$\begin{array}{l}\text { Percentage } \\
\text { NOR inactivity }\end{array}$} & \multirow[b]{2}{*}{ Tota } \\
\hline & $\begin{array}{l}\text { Both NORs } \\
\text { active }\end{array}$ & $\begin{array}{l}\text { One inactive } \\
\text { NOR }\end{array}$ & & \\
\hline SS & 137 & 23 & 14.4 & 160 \\
\hline SI & 132 & 28 & 17.5 & 160 \\
\hline II & 26 & 14 & 35.0 & 40 \\
\hline Total & 295 & 65 & & 360 \\
\hline
\end{tabular}

test grouping SS and SI males $\left(\chi_{(2)}^{2}=7.49, P=0.001-\right.$ $0.01)$. Thus, the $S_{11}$ inversion influences NOR activity on $\mathrm{L}_{3}$ chromosomes since, at least in the homozygous state, the frequency of cells showing an inactive NOR is significantly increased.

The frequencies of individuals of both sexes and of the three $S_{11}$ karyotypes (SS, SI and II) are summarized in Table 3. The frequencies of standard and inverted $\mathrm{S}_{11}$ chromosomes did not differ between males and females, as demonstrated by contingency chi-squared tests in the five populations in which such analysis was possible (Table 4). A second approach to this feature was used by analysing segregation of $S_{11}$ unequal bivalents with respect to the $\mathrm{X}$ chromosome in heterozygous males. For this purpose, 173 second metaphase II cells from SI males were analysed, of which 39 possessed a standard (S) $S_{11}$ chromosome plus the $X$ chromosome, 43 showed an inverted (I) $S_{11}$ and the $X$, and the remaining lacked the $\mathrm{X}$ chromosome. Of this last group 50 carried a standard $S_{11}$ and 41 an inverted $S_{11}$. A chi-squared test demonstrated that $S_{11}$ unequal bivalents of SI males segregate at random with respect to the $\mathrm{X}$ chromosome at the first meiotic division $\left(\chi_{(3)}^{2}=1.59, P=0.50-0.70\right)$.

Inverted $S_{11}$ chromosomes were present in all seven wild populations analysed. Their frequency was always low, and there were only slight differences between populations. A contingency chi-squared test demonstrated no significant differences between populations for the frequencies of $\mathrm{S}$ and I chromosomes $\left(\chi_{(6)}^{2}=\right.$ 6.57, $P=0.30-0.50)$ (Table 5).

To test the Hardy-Weinberg equilibrium, given the absence of inversion homozygotes in most populations 
Table 3 Karyomorph and chromosomal frequencies for $\mathrm{S}_{11}$ polymorphism in seven natural populations of $A$. strepens

\begin{tabular}{|c|c|c|c|c|c|c|c|c|c|c|c|c|}
\hline \multirow[b]{2}{*}{ Population } & \multicolumn{4}{|l|}{ Males } & \multicolumn{4}{|l|}{ Females } & \multicolumn{4}{|l|}{ Total } \\
\hline & SS & SI & II & $q$ & SS & SI & II & $q$ & SS & ȘI & II & $q$ \\
\hline \multirow[t]{2}{*}{$\mathrm{CU}$} & 82 & 12 & 2 & & 48 & 10 & 0 & & 130 & 22 & 2 & \\
\hline & 0.854 & 0.125 & 0.021 & 0.083 & 0.828 & 0.172 & 0 & 0.086 & 0.844 & 0.143 & 0.013 & 0.084 \\
\hline \multirow[t]{2}{*}{ DU } & 20 & 3 & 0 & & 14 & 3 & 0 & & 34 & 6 & 0 & \\
\hline & 0.870 & 0.130 & 0 & 0.065 & 0.824 & 0.176 & 0 & 0.088 & 0.850 & 0.150 & 0 & 0.075 \\
\hline \multirow[t]{2}{*}{ GA } & 27 & 6 & 0 & & 20 & 1 & 0 & & 47 & 7 & 0 & \\
\hline & 0.818 & 0.182 & 0 & 0.091 & 0.952 & 0.048 & 0 & 0.024 & 0.878 & 0.130 & 0 & 0.065 \\
\hline \multirow[t]{2}{*}{$\mathrm{AB}$} & 21 & 1 & 0 & & 16 & 3 & 0 & & 37 & 4 & 0 & \\
\hline & 0.955 & 0.045 & 0 & 0.023 & 0.842 & 0.158 & 0 & 0.079 & 0.902 & 0.098 & 0 & 0.049 \\
\hline \multirow[t]{2}{*}{$\mathrm{CP}$} & 20 & 0 & 0 & & 19 & 1 & 0 & & 39 & 1 & 0 & \\
\hline & 1.000 & 0 & 0 & 0 & 0.950 & 0.050 & 0 & 0.025 & 0.975 & 0.025 & 0 & 0.013 \\
\hline \multirow[t]{2}{*}{$\mathrm{CV}$} & - & - & - & & 35 & 4 & 0 & & 35 & 4 & 0 & \\
\hline & - & - & - & - & 0.897 & 0.103 & 0 & 0.051 & 0.897 & 0.103 & 0 & 0.051 \\
\hline \multirow[t]{2}{*}{ PA } & 22 & 4 & 0 & & 20 & 1 & 0 & & 42 & 5 & 0 & \\
\hline & 0.846 & 0.154 & 0 & 0.077 & 0.952 & 0.048 & 0 & 0.024 & 0.894 & 0.106 & 0 & 0.053 \\
\hline \multirow[t]{2}{*}{ Total } & & & & & & & & & 364 & 49 & 2 & \\
\hline & & & & & & & & & 0.877 & 0.118 & 0.005 & 0.064 \\
\hline
\end{tabular}

$\mathrm{S}=$ Standard $\mathrm{S}_{11}, \mathrm{I}=$ inverted $\mathrm{S}_{11}, q=$ frequency of inverted chromosomes

Table 4 Comparison of $S_{11}$ chromosome frequencies between sexes

\begin{tabular}{|c|c|c|c|c|c|c|}
\hline \multirow[b]{3}{*}{ Population } & \multicolumn{4}{|c|}{$\begin{array}{l}\text { Number of } \mathrm{S}_{11} \\
\text { chromosomes }\end{array}$} & \multirow[b]{3}{*}{$\chi_{(1)}^{2}$} & \multirow[b]{3}{*}{$P$} \\
\hline & \multicolumn{2}{|c|}{ Males } & \multicolumn{2}{|c|}{ Females } & & \\
\hline & $S$ & I & $S$ & I & & \\
\hline $\mathrm{CU}$ & 176 & 16 & 106 & 10 & 0.015 & $0.90-0.95$ \\
\hline DU & 43 & 3 & 31 & 3 & 0.002 & $0.95-0.98$ \\
\hline GA & 60 & 6 & 41 & 1 & 0.960 & $0.70-0.80$ \\
\hline $\mathrm{AB}$ & 43 & 1 & 35 & 3 & 0.442 & $0.50-0.70$ \\
\hline PA & 48 & 4 & 41 & 1 & 0.460 & $0.30-0.50$ \\
\hline
\end{tabular}

we normalized karyotypic frequencies by angular transformation (Table 6). These analyses demonstrated that the observed karyotypic frequencies fit those expected under the Hardy-Weinberg equilibrium.

Finally, a female that was gravid when caught in the field laid several egg pods in the laboratory, allowing the analysis of 98 embryos cytologically. This female was heterozygous for the $S_{11}$ inversion, thus the transmission of $S$ and I chromosomes through this specimen could be analysed. Keeping in mind that this female
Table 5 Comparison of $\mathrm{S}$ and I $\mathrm{S}_{11}$ chromosome frequencies between populations

\begin{tabular}{lrrrr}
\hline & \multicolumn{3}{l}{ Number of $\mathrm{S}_{11}$ chromosomes } \\
\cline { 2 - 4 } Population & S type & I type & Total & \multicolumn{1}{l}{$q$} \\
\hline CU & 282 & 26 & 308 & 0.084 \\
DU & 74 & 6 & 80 & 0.075 \\
GA & 101 & 7 & 108 & 0.065 \\
AB & 78 & 4 & 82 & 0.049 \\
CP & 79 & 1 & 80 & 0.013 \\
CV & 74 & 4 & 78 & 0.051 \\
PA & 89 & 5 & 94 & 0.053 \\
\hline \multirow{2}{*}{$q=$ Frequency of inverted chromosomes. }
\end{tabular}

was collected at population $\mathrm{CP}$, which showed the lowest frequency of inverted $S_{11}$ chromosomes (all 20 males were SS and only this female out of 20 analysed carried an I chromosome), it is reasonable to assume that she had been fertilized by an SS male. Out of 98 embryos, 47 were SS and 51 were SI, which implies a rate of transmission for the inverted $S_{11}$ chromosome equal to 0.52 , a figure which does not differ significantly from the expected Mendelian value $(0.50)$ $\left(\chi_{(1)}^{2}=0.16, P=0.50-0.70\right)$. 
Table 6 Tests for Hardy-Weinberg equilibrium with karyotypic frequencies normalized by angular transformation*. Note that none of the normalized karyotypic frequencies is higher than the theoretical value $( \pm 1.96)$

\begin{tabular}{|c|c|c|c|c|c|}
\hline Population & & SS & SI & II & $q_{\mathrm{i}}$ \\
\hline \multirow[t]{3}{*}{$\mathrm{CU}$} & Observed & 0.844 & 0.143 & 0.013 & \multirow[t]{3}{*}{0.084} \\
\hline & Equilibrium & 0.840 & 0.154 & 0.007 & \\
\hline & Normalized & 0.096 & -0.270 & 0.535 & \\
\hline \multirow[t]{3}{*}{$\mathrm{DU}$} & Observed & 0.850 & 0.150 & 0.000 & \multirow[t]{3}{*}{0.075} \\
\hline & Equilibrium & 0.856 & 0.138 & 0.006 & \\
\hline & Normalized & -0.076 & 0.153 & -0.694 & \\
\hline \multirow[t]{3}{*}{ GA } & Observed & 0.870 & 0.130 & 0.000 & \multirow[t]{3}{*}{0.065} \\
\hline & Equilibrium & 0.874 & 0.122 & 0.004 & \\
\hline & Normalized & -0.062 & 0.125 & -0.658 & \\
\hline \multirow[t]{3}{*}{$\mathrm{AB}$} & Observed & 0.902 & 0.098 & 0.000 & \multirow[t]{3}{*}{0.048} \\
\hline & Equilibrium & 0.906 & 0.091 & 0.002 & \\
\hline & Normalized & -0.061 & 0.108 & -0.405 & \\
\hline \multirow[t]{3}{*}{$\mathrm{CP}$} & Observed & 0.975 & 0.025 & 0.000 & \multirow[t]{3}{*}{0.013} \\
\hline & Equilibrium & 0.974 & 0.025 & 0.001 & \\
\hline & Normalized & 0.028 & -0.028 & -0.125 & \\
\hline \multirow[t]{3}{*}{$\mathrm{CV}$} & Observed & 0.897 & 0.103 & 0.000 & \multirow[t]{3}{*}{0.051} \\
\hline & Equilibrium & 0.901 & 0.096 & 0.003 & \\
\hline & Normalized & -0.059 & 0.103 & -0.484 & \\
\hline \multirow[t]{3}{*}{ PA } & Observed & 0.894 & 0.106 & 0.000 & \multirow[t]{3}{*}{0.043} \\
\hline & Equilibrium & 0.916 & 0.082 & 0.002 & \\
\hline & Normalized & -0.364 & 0.399 & -0.434 & \\
\hline
\end{tabular}

*Normalized karyotypic frequency:

$\mathrm{fr}=\frac{\arcsin \sqrt{P \text { obs. }-\arcsin } \sqrt{P \text { exp. }}}{\sqrt{820.8(2 / N)}}$.

\section{Discussion}

The $S_{11}$ pericentric inversion in $A$. strepens is an absolute crossover suppressor between standard and inverted sequences in the heterozygous $S_{11}$ bivalents. It is also a partial crossover suppressor in the $S_{9}$ and $S_{10}$ bivalents, whose only chiasma is distally located at a higher frequency in SI males than in SS males, although mean cell chiasma frequency was not significantly different (Cabrero \& Camacho, 1982). In this study this latter finding was re-examined in order to test the possible tendency of variation of chiasma frequency over time in a sample of the population $\mathrm{CU}$ caught 5 years after the initial study. Our results confirm previous observations: although mean cell chiasma frequency in SI males was lower than in SS males, the difference was not statistically significant. However, when mean cell chiasma frequency in SS males was compared between the first sample in $1980(\bar{x}=18.53)$ and the present sample, caught in $1985(\bar{x}=17.88)$, there was a significant decrease after five generations (Table 7). In SI males, on the other hand, there was no
Table 7 Comparisons of mean cell chiasma frequencies in SS and SI males sampled in 1980 and 1985

\begin{tabular}{|c|c|c|c|c|c|c|c|c|}
\hline \multirow[b]{2}{*}{ Year } & \multicolumn{3}{|c|}{ SS males } & \multicolumn{2}{|c|}{ SI males } & \multicolumn{3}{|c|}{$\mathrm{SS}+\mathrm{SI}$ males } \\
\hline & $\bar{x}$ & $\varepsilon$ & $n$ & $\bar{x}$ & $\varepsilon$ & $n \bar{x}$ & $\varepsilon$ & $n$ \\
\hline 80 & 18.53 & 0.143 & 54 & 17.60 & 0.484 & 718.43 & 0.142 & 61 \\
\hline 1985 & $\begin{array}{l}17.88 \\
t=3.8 \\
P<0.0\end{array}$ & $\begin{array}{l}7^{0.088} \\
001\end{array}$ & 8 & $\begin{array}{l}17.35 \\
t=0.4 \\
P=0.5\end{array}$ & $\begin{array}{l}0.288 \\
4 \\
50-0.70\end{array}$ & $\begin{array}{cc}8 & 17.62 \\
& t=3.7 \\
& P<0 .\end{array}$ & $\begin{array}{l}0.161 \\
6 \\
001\end{array}$ & 16 \\
\hline
\end{tabular}

significant difference between the $1980(\bar{x}=17.60)$ and $1985(\bar{x}=17.35)$ samples. As a whole, mean cell chiasma frequency decreased significantly in population CU between $1980 \quad(\bar{x}=18.43)$ and 1985 $(\bar{x}=17.62)$. Thus, it seems that the total amount of genetic variation caused by meiotic crossing-over tends toward reduction, which is more apparent in SS males with a higher mean chiasma frequency. This means that natural selection favours genetic variants with reduced amounts of genetic recombination. In this context, SI males could be considered more fit than SS males on the basis of the crossover suppression exerted by the $S_{11}$ inversion.

Population CU passed through a bottleneck in 1973 due to flooding which presumably killed most grasshoppers. After this event, genotypes releasing large amounts of genetic variation by means of meiotic recombination may have been favoured by natural selection among individuals which recolonized population CU. After several generations, the progressive adaptation to the new habitat may have favoured low levels of genetic variation, which would explain the tendency observed in our sample from 1980 to 1985.

Our analyses of the effects on NOR expression suggest that II males have significantly less NOR activity than SS and SI males. Similar interchromosomal effects on NOR activity in the grasshoppers $E y$ prepocnemis plorans (Cabrero et al., 1987) and Locusta migratoria (Salcedo et al., 1988) were related to the presence of B chromosomes. Although, however, the mechanism for these effects is presently unknown, it must involve a decrease in the capacity of II males to synthesize ribosomal RNA, since the expression of r-RNA genes is reduced. Consequently, II males could be less fit than SS and SI males; this could explain the low frequency of I chromosomes in natural populations.

Our frequency analysis demonstrated, however, that $S_{11}$ inversion polymorphism is broadly distributed in the Iberian Peninsula, since in all populations in which a high number of individuals have been analysed, at 
least one individual appeared with the $S_{11}$ inversion. This is true for all seven populations studied in the province of Granada (this article) and for two populations from the provinces of Alicante and Avila studied by Suja et al. (1986). It is remarkable that inverted chromosomes are equally rare in all populations, the mean frequency being 6.4 per cent. The maintenance of similar rates of polymorphism in wild populations merits some consideration. Firstly, the frequency of polymorphism seems to be stable over time, since in population $\mathrm{CU}$ the frequency of $\mathrm{S}$ and I chromosomes did not change significantly from 1980 to 1985 (Table 8). Secondly, a SI female transmitted S and I chromosomes at Mendelian rates (0.5). Thirdly, since $A$. strepens shows only one chromosome pair with NOR activity, any reduction in the level of NOR expression may be critical, as it would dramatically decrease the potential for protein synthesis. In species with more than one active NOR this is not necessarily so, since minimal levels of $r$-RNA production are guaranteed by the number of existing NORs. Thus, II males may be at a disadvantage with respect to SS and SI males due to the formers' reduced capacity for protein synthesis. We could quantify this disadvantage by counting the frequency with which both NORs are active in the different types of males. SS and SI males showed very similar figures (average 84 per cent), while in II males 65 per cent of the cells showed NOR activity maximum, making this component of fitness in II males 0.77 times that of SS and SI males.

The stability of $S_{11}$ polymorphism, the disadvantage of II males in ribosomal RNA production, and the plausible advantage of SI males versus SS males through the maintenance of a supergene, suggest the possibility that polymorphism is maintained in natural populations by heterosis. The absence of a significant excess of heterozygotes with respect to HardyWeinberg equilibrium could be explainable if the heterozygous advantage depended on an increase in fecundity rather than in viability (White, 1973). Alternatively, inbreeding may generate more homozygotes (Hewitt, 1979). In fact, inbreeding has been reported in grasshopper populations (Cabrero \& Camacho, 1987). The lower fitness of II males versus SS males may explain the low frequencies of I chromosomes in all natural populations analysed, since equilibrium frequencies caused by heterosis are determined exclusively by the selective coefficients of both homozygotes (see White, 1973).

Another way in which $S_{11}$ inversion polymorphism may be maintained is suggested by its broad distribution and the low frequencies of inverted chromosomes in all populations, as the result of a mutation-selection equilibrium. The possibility of recurrence of the $S_{11}$ inversion, assuming that the neotelomeric zone represents a fragile point of breakage in the standard $S_{11}$ chromosome, was pointed out by Suja et al. (1986). If this were the case, the rate of mutation can be calculated by the formula of mutation-selection equilibrium in the case of selection against only one homozygote $(S=0.23)$ and given the mean value of all seven populations analysed in this article $(\hat{q}=0.064)$. Thus, a mutation rate of $9.42 \times 10^{-4}$ would be necessary to reach an equilibrium frequency of inverted chromosomes equal to 0.064 with a selection coefficient of 0.23 acting against II individuals. Although this is actually a high frequency, it is not very different from that observed in Keyacris scurra, where at least one individual in a thousand seems to be heterozygous for some kind of unique, and presumably newly arisen, chromosomal rearrangement usually a translocation (White, 1961, 1963).

The recurrence of the $S_{11}$ inversion is testable in the laboratory by controlled crosses to determine whether two parents lacking this rearrangement produce descendants with the $S_{11}$ inversion. This analysis would, however, require a large numbers of crosses. Alternative methods must therefore be developed; direct analysis of the fragility of the neotelomeric zone by inducing chromosomal breakage with radiation to adult individuals, or cell culture, in the laboratory are two possibilities. At present we are trying to culture cells for further studies of the frequency of the $S_{11}$ inversion in Aiolopus strepens.

Table 8 Frequency of $S_{11}$ polymorphism in population CU 5 years apart

\begin{tabular}{|c|c|c|c|c|c|c|c|c|c|c|}
\hline \multirow[b]{2}{*}{ Year } & \multicolumn{4}{|c|}{$\begin{array}{l}\text { Number of individuals } \\
\text { with karyomorph }\end{array}$} & \multicolumn{3}{|c|}{$\begin{array}{l}\text { Number of } \\
\text { chromosomes }\end{array}$} & \multirow{2}{*}{$\begin{array}{l}\text { Frequency } \\
\text { of I } \\
\text { chromosome }\end{array}$} & \multirow[b]{2}{*}{$\chi_{(1)}^{2}$} & \multirow[b]{2}{*}{$P$} \\
\hline & SS & SI & II & Total & $\mathrm{S}$ & $I$ & Total & & & \\
\hline 1980 & 97 & 12 & 0 & 109 & 206 & 12 & 218 & 0.055 & 1.23 & n.s. \\
\hline 1985 & 130 & 22 & 2 & 154 & 282 & 26 & 308 & 0.084 & & \\
\hline
\end{tabular}




\section{Acknowledgements}

This work was partially supported by grants from the Dirección General de Investigación Científica y Técnica (no. PB87-0886) and Plan Andaluz de Investigación, Grupo no. 3094 (Spain).

\section{References}

CABRERO, J., ALCHE, J. D. AND CAMACHO, J. P. M. 1987. Effects of B chromosomes of the grasshopper Eyprepocnemis plorans on nucleolar organiser regions activity. Activation of a latent NOR on a B chromosome fused to an autosome. Genome, 29, 116-121.

CABRERO, J. AND CAMACHO, J. P. M. 1982. Pericentric inversion polymorphism in Aiolopus strepens (Orthoptera: Acrididae): effects on chiasma formation. Caryologia, 35, 4, 411-424.

CABRERO, J. AND CAMACHO, J. P. M. 1987. Inbreeding in a natural population of the grasshopper Chorthippus nevadensis. Heredity, 58, 57-58.

HEWITT, G. M. 1979. Grasshoppers and Crickets. Animal Cytogenetics, Vol. 3: Insecta 1 Orthoptera, Gebrüder Borntraeger, Berlin.

LEWONTIN, R. C. AND WHITE, M. J. D. 1960. Interaction between inversion polymorphisms of two chromosome pairs in the grasshopper Moraba scurra. Evolution, 14, 116-129.
RUFAS, J. S., ITURRA, P., DE SOUZA, w. AND ESPONDA, P. 1982. Simple silver staining procedure for the location of nucleolus and nucleolar organizer under light and electron microscopy. Arch. Biol., 93, 267-274.

SALCEDO, F. J., VISERAS, E. AND CAMACHO, J. P. M. 1988. The B-chromosomes of Locusta migratoria. III. Effects on the activity of nucleolar organizer regions. Genome, 30 , 387-394.

SUJA, J. A., CAMACHO, J. P. M., CABRERO, J. AND RUFAS, J. S. 1986. Analysis of a centric shift in the $S_{11}$ chromosome of Aiolopus strepens (Orthoptera: Acrididae). Genetica, 70 , 211-216.

WHITE, M. J. D. 1958. Restrictions on recombination in grasshopper populations and species. Cold Spr. Harb. Symp. Quant. Biol., 23, 307-317.

WHITE, M. J. D. 1961. Cytogenetics of the grasshopper Moraba scurra. VI. A spontaneous pericentric inversion. Aust. J. Zool., 9, 784-790.

whITE, M. J. D. 1963. Cytogenetics of the grasshopper Moraba scurra. VIII. A complex spontaneous translocation. Chromosoma, 14, 140-145.

WHITE, M. J. D. 1973. Animal Cytology and Evolution, 3rd edn, Cambridge University Press, London.

White, M. J. D., LEwontin, R. C. AND ANDREW, L. E. 1963. Cytogenetics of the grasshopper Moraba scurra. VII. Geographic variation of adaptive properties of inversions. Evolution, 17, 147-162. 